\title{
Uji Aktivitas Antibakteri Ekstrak Kloroform dan Ekstrak Etanol Biji Bidara Laut (Strychnos ligustrina BI) Terhadap Staphylococcus aureus ATCC 25923 dan Salmonella thypi
}

\author{
ETI SUMIATI \\ Program Studi S1 Keperawatan, Sekolah Tinggi Ilmu Kesehatan Mataram \\ Jl. Swaskarsa III No.11-13 Kekalik, Mataram \\ email: etisumiati03@yahoo.com
}

\begin{abstract}
A research has been conducted on the antibacterial activity of Strychnos ligustrina seeds against Staphylococcus aureus ATCC 25923 in vitro. Strychnos ligustrina seeds extracted using two solvents, namely chloroform (chloroform extract) and 70\% ethanol (ethanol extract) and analysis of the chemical content of the extract by thin layer chromatography and paper chromatography. The results of this study are expected to provide data activity of Strychnos ligustrina seeds as antibacterial scientifically.

In this study, the chloroform extract and ethanol extract of Strychnos ligustrina seeds obtained by the filtration method with Soxhlet apparatus. Antibacterial activity test of chloroform extract and ethanol extract $70 \%$ from Strychnos ligustrina seeds performed using liquid dilution method, the parameters used are the MIC (minimum inhibitory concentration) and MKC (minimum killing concentration). MIC is determined by turbidity or clarity of the test solution, while MKC determined by scraping the respective concentrations of the extract / test solution on blood agar medium.

The results showed that the chloroform extract and ethanol extract of Bidara Laut seed has antibacterial activity against Staphylococcus aureus ATCC 25923 and Salmonella thypi. MIC of each test extracts (chloroform and ethanol 70\%) could not be determined because both of the test extract produce turbid color, while the MIC of the second test extract was 3.62\% b/v for Salmonella thypi, $8.75 \%$ for Staphylococcus aureus ATCC 25923 (Strychnos ligustrina seeds chloroform extract), 22.5\% for Salmonella thypi and 15\% for Staphylococcus aureus ATCC 25923 (Strychnos ligustrina seeds ethanol extract). Results of thin layer chromatography and paper chromatography showed that the chloroform extract seeds contain alkaloids and steroids / triterpenoids, whereas the $70 \%$ ethanol extract contains alkaloids, tannins and steroids/triterpenoids.
\end{abstract}

Keywords: antibacterial, chloroform extract, ethanol 70\% extract, Strychnos ligustrina seeds, Salmonella thypi, Staphylococcus aureus

\section{PENDAHULUAN}

Bakteri merupakan salah satu mikroorganisme yang banyak peranannya dalam kehidupan manusia, ada yang menguntungkan dan ada pula yang merugikan. Bakteri yang merugikan dapat menyebabkan bahaya, yaitu menginfeksi manusia, hewan, serta tanaman, menimbulkan penyakit yang berkisar dari infeksi ringan sampai kepada kematian. Penanganan penyakit yang disebabkan oleh bakteri dapat dilakukan dengan pengobatan. Pengobatan ini bertujuan untuk menghambat/membunuh bakteri penyebab penyakit. Melihat besarnya resiko serta masalah yang ditimbulkan oleh penyakit yang disebabkan oleh bakteri, menyebabkan semakin kuatnya keinginan para peneliti untuk mendapatkan obat antibakteri baru yang lebih baik dari obat-obat sebelumnya. Obat/senyawa antibakteri baru tersebut dapat diperoleh dari bahan alam (tumbuh-tumbuhan). Peluang untuk mendapatkan senyawa/obat antibakteri dari bahan alam lebih besar (memungkinkan), karena mengingat Indonesia adalah negara yang memiliki beranekaragam jenis tanaman, terutama yang dapat digunakan/dimanfaatkan sebagai bahan obat.

Di Dompu-NTB, tanaman bidara laut atau yang dikenal dengan nama Songga oleh masyarakat Dompu digunakan secara 
tradisional untuk mengobati berbagai macam penyakit. Beberapa contoh penyakit yang dapat disembuhkan oleh tanaman bidara laut adalah demam, diare, bisul, borok, malaria. Bagian tanaman bidara laut yang sering digunakan oleh masyarakat Dompu untuk pengobatan adalah buah dan batang (Rachmat $d k k, 2002)$.

Tanaman S. ligustrina $\mathrm{Bl}$ mengandung senyawa alkaloid, tanin, steroid/triterpenoid. Senyawa-senyawa tersebut lebih dikenal memiliki aktivitas sebagai antibakteri. Melihat senyawa yang terkandung dalam tanaman $S$. ligustrina $\mathrm{B} 1$ dan pemanfaatan secara empiris dari tanaman S. ligustrina B1, sehingga perlu dilakukan penelitian untuk menguji aktivitas antibakteri dari tanaman tersebut. Pada penelitian ini, bagian tanaman yang akan diuji aktivitas antibakterinya adalah biji dari tanaman bidara laut (S. ligustrina $\mathrm{Bl}$ ). Berdasarkan senyawa yang terkandung dalam biji bidara laut, maka dilakukan penyarian/ekstraksi biji $S$. ligustrina dengan dua pelarut, yaitu kloroform dan etanol $70 \%$ menggunakan metode penyarian dengan alat Soxhlet. Dengan ekstraksi menggunakan dua pelarut ini diharapkan senyawa-senyawa aktif yang terkandung dalam serbuk biji bidara laut (S. ligustrina $\mathrm{Bl}$ ) dapat tersari semua dengan sempurna (Voigh, 1995). Penelitian Mursiti dan Hertiani (2002) menggunakan ekstrak kloroform biji Phaleria macrocarpa (Scheff.) Boerl. menunjukkan bahwa dalam ekstrak tersebut mengandung senyawa alkaloid dan terpenoid. Jamal $d k k$ (2001) melakukan ekstraksi (penapisan fitokimia) kulit batang Garcinia celebica dan $G$. tetandra menggunakan pelarut eter, alkohol dan air, hasilnya menunjukkan bahwa ekstrak eter mengandung minyak atsiri, sterol/triterpena, alkaloid basa dan lain-lain, sedangkan ekstrak alkohol mengandung senyawa tanin, glikosida steroid dan lain-lain, sedangkan ekstrak air mengandung glukosida dan saponin.

Untuk mengetahui apakah suatu senyawa/obat memiliki aktivitas antibakteri yang berspektrum luas ataupun sempit (Ganiswarna, 1995) maka pada penelitian ini digunakan dua golongan bakteri, yaitu bakteri Gram positif (Stapylococcus aureus ATCC
25923) dan Gram negatif (Salmonella thypi). Penggunaan $S$. aureus dan $S$. thypi juga dimaksudkan untuk mengetahui apakah ekstrak kloroform dan ekstrak etanol 70\% biji bidara laut dapat menghambat/membunuh kedua bakteri tersebut, dilihat dari kadar hambat minimum (KHM) dan kadar bunuh minimum (KBM).

\section{METODE}

Pembuatan Serbuk (Simplisia) Biji Bidara Laut. Buah bidara laut (Strychnos ligustrina Bl) dibersihkan, kemudian dibelah/dipecah. Buah yang telah dibelah dicuci bersih dan dikeringkan di bawah sinar matahari dengan ditutup kain hitam, setelah kira-kira setengah kering biji diambil dan dipisahkan dari dagingnya. Biji yang telah pisah tadi dijemur lagi sampai kering sehingga diperoleh simplisia. Simplisia yang diperoleh tadi diblender sampai halus dan disimpan dalam wadah yang tertutup rapat.

Pembuatan Ekstrak. Ekstrak kloroform dan ekstrak etanol $70 \%$ biji bidara laut (Strychnos ligustrina $\mathrm{Bl}$ ) diperoleh dengan metode penyarian dengan alat soxhlet. Serbuk biji bidara laut yang digunakan adalah sebanyak 100 g. Serbuk biji bidara laut dibungkus dengan kertas saring, kemudian dimasukkan ke dalam alat soxhlet dan ditambahkan kloroform. Sari kloroform ini kemudian diuapkan dengan menggunakan retaevaporator, sehingga berbentuk ekstrak kental. Ekstrak ini disebut sebagai ekstrak kloroform biji bidara laut. Ampas sisa penyarian dengan kloroform diangin-anginkan kemudian dikeringkan. Ampas sisa penyarian yang pertama (dengan kloroform) tadi, kemudian diekstraksi lagi dengan alat soxhlet dengan menggunakan pelarut etanol $70 \%$. Proses penyarian dengan etanol ini, sama halnya dengan proses penyarian dengan kloroform tadi. Sari hasil penyarian kemudian diuapkan dengan rotaevaporator suhu $70^{\circ} \mathrm{C}$ sampai diperoleh ekstrak kental. Ekstrak ini disebut sebagai ekstrak etanol $70 \%$ biji bidara laut.

Pemeriksaan Etanol. Setelah didapatkan ekstrak etanol $70 \%$ biji bidara laut, kemudian dilakukan pemeriksaan etanol dengan cara, 
sebanyak $5 \mathrm{ml}$ larutan dari ekstrak etanol 70\% biji bidara laut diambil dan ditambahkan $1 \mathrm{ml}$ $\mathrm{NaOH} \quad 1 \quad \mathrm{~N}$ (normalitas) perlahan-lahan (setelah 3 menit) tambahkan $2 \mathrm{ml}$ Iodium 0,1 $\mathrm{N}$ setelah itu akan timbul bau Iodoform dan terbentuk endapan kuning dalam waktu 30 menit. Apabila dalam ekstrak tersebut tidak timbul bau Iodoform dan tidak terbentuk endapan berwarna kuning, menunjukkan bahwa ekstrak etanol $70 \%$ biji bidara laut bebas dari etanol. Etanol dengan kadar 20\% ke atas akan sulit ditumbuhi kapang dan kuman (Anonim, 1986). Tujuan penghilangan etanol adalah untuk menghindari pengaruh dari etanol, dimana etanol dapat membunuh bakteri sehingga dikhawatirkan mempengaruhi aktivitas antibakteri dari ekstrak etanol $70 \%$ biji bidara laut.

Pengujian daya antibakteri. Bakteri $S$. aureus ATCC 25923 dan S. thypi diambil dari suatu biakan dengan menggunakan ose bulat sebanyak satu koloni, digoreskan pada masingmasing media NA, diinkubasi selama 18-24 jam, pada temperatur $37^{\circ} \mathrm{C}$. Setelah biakan $S$. aureus dan $S$. thypi tersebut tumbuh, tabung tersebut disimpan dalam almari pendingin (suhu $4^{0} \mathrm{C}$ ) sebagai stok. Satu ose bakteri $S$. aureus ATCC 25923 dan S. thypi dari stok disuspensikan dalam $2 \mathrm{ml}$ BHI, diinkubasi pada suhu $37^{\circ} \mathrm{C}$ selama $18-24$ jam. Diambil $0,2 \mathrm{ml}$ suspensi bakteri dalam $2 \mathrm{ml}$ BHI dan dimasukkan ke dalam tabung reaksi yang telah diisi media BHI $2 \mathrm{ml}$ dan diinkubasi selama 34 jam pada suhu $37^{\circ} \mathrm{C}$. Selanjutnya suspensi diencerkan dengan $\mathrm{NaCl}$ 0,9\% fisiologis steril sampai didapat kekeruhan $10^{8} \mathrm{CFU} / \mathrm{ml}$ atau sama dengan kekeruhan standard Mc Farland, suspensi tersebut diencerkan dengan BHI DS untuk mendapatkan konsentrasi $10^{6} \mathrm{CFU} / \mathrm{ml}$ dengan cara diambil $0,1 \mathrm{ml}$ suspensi bakteri dan dimasukkan ke dalam 9,9 ml BHI DS cair sampai volume $10 \mathrm{ml}$.

Uji pendahuluan meliputi uji kelarutan ekstrak dan uji pendahuluan aktivitas antibakteri ekstrak kloroform dan ekstrak etanol biji bidara laut dengan membuat larutan sampel dengan konsentrasi awal ekstrak kloroform dan ekstrak etanol biji bidara laut sebagai berikut: $100 \% \mathrm{~b} / \mathrm{v}, 50 \% \mathrm{~b} / \mathrm{v}, 25 \% \mathrm{~b} / \mathrm{v}$, $12,5 \% \mathrm{~b} / \mathrm{v}, 6,25 \% \mathrm{~b} / \mathrm{v}$ dan $3,12 \% \mathrm{~b} / \mathrm{v}$ dan dilakukan berdasarkan metode dilusi cair. Untuk mengetahui Kadar Bunuh Minimum (KBM), dilakukan penggoresan untuk masingmasing konsentrasi pada media yakni media agar darah untuk $S$. aureus dan $S$. thypi yang selanjutnya diinkubasikan selama 18-24 jam pada suhu $37^{\circ} \mathrm{C}$. Dilakukan pengamatan dengan melihat apakah terjadi pertumbuhan bakteri pada masing-masing hasil goresan guna mengetahui Kadar Bunuh Minimum (KBM). Konsentrasi ekstrak uji akan berubah/berkurang menjadi setengah konsentrasi setelah penambahan suspensi bakteri, dimana konsentrasi akan menjadi 50\% $\mathrm{b} / \mathrm{v}, 25 \% \mathrm{~b} / \mathrm{v}, 12,5 \% \mathrm{~b} / \mathrm{v}, 6,25 \% \mathrm{~b} / \mathrm{v}, 3,12 \% \mathrm{~b} / \mathrm{v}$ dan $1,56 \% \mathrm{~b} / \mathrm{v}$. konsentrasi tersebut adalah konsentrasi akhir atau konsentrasi kontak (konsentrasi uji). Uji Sesungguhnya. Masingmasing ekstrak uji, dibuat stok larutan sampel yang baru, kemudian dibuat kisaran konsentrasi baru yang ditentukan berdasarkan hasil KHM dan KBM pada uji pendahuluan aktivitas antibakteri ekstrak kloroform dan ekstrak etanol 70\% biji bidara laut.

Analisis Kandungan Kimia Ekstrak. Identifikasi senyawa kandungan kimia dari ekstrak kloroform dan ekstrak etanol 70\% biji bidara laut dilakukan dengan menggunakan metode kromatografi lapis tipis dan kromatografi kertas. Senyawa yang diidentifikasi adalah alkaloid, tanin, dan steroid/triterpenoid. Sampel yang digunakan adalah ekstrak kloroform dan ekstrak etanol $70 \%$ biji bidara laut (Strychnos ligustrina $\mathrm{Bl}$ ). (1) Identifikasi Alkaloid. Sampel (ekstrak kloroform dan ekstrak etanol 70\%) biji bidara laut serta larutan pembanding ditotolkan. Larutan pembanding: Larutan cafein. Fase diam: Silika gel F. Fase gerak: Kloroform:dietilamina (90:10). Deteksi: Dilihat pada UV $254 \mathrm{~nm}$ dan UV $366 \mathrm{~nm}$ serta disemprot dengan pereaksi Dragendroff. (2). Identifikasi Tanin. Larutan pembanding: Tanin. Fase diam: Kertas Whattman no.1. Fase gerak: Butanol:Asam asetat:Water (4:1:5). Deteksi: (1) Dilihat pada UV $254 \mathrm{~nm}$ dan UV $366 \mathrm{~nm}$ (2) Pereaksi semprot $\mathrm{FeCl}_{3}$. (3) Identifikasi Steroid/Triterpenoid. Larutan pembanding: Klerak. Fase diam: Silika gel F. Fase gerak: Metanol:Air (1:1). Deteksi pada 
UV 254 nm, UV 366nm dan disemprot dengan pereaksi Liebermann-Burchard (LB).

Analisis Data. Analisis data dilakukan berdasarkan pengamatan terhadap pertumbuhan koloni bakteri pada media biakan pada berbagai seri konsentrasi yang telah dibuat. Penentuan konsentrasi hambat minimum (KHM) dilakukan pengamatan berdasarkan kejernihan/kekeruhan tabung/larutan uji, sedangkan penentuan konsentrasi bunuh minimum (KBM) ditandai dengan ada tidaknya pertumbuhan bakteri pada media biakan (media agar darah). Analisis kandungan kimia ekstrak dilakukan dengan kromatografi lapis tipis (senyawa alkaloid dan steroid/triterpenoid) dan kromatografi kertas (senyawa tanin). Pada pemeriksaan/identifikasi golongan senyawa dalam ekstrak kloroform dan ekstrak etanol biji bidara laut, bercak-bercak pada kromatogram diidentifikasi menggunakan sinar UV $254 \mathrm{~nm}$, UV $366 \mathrm{~nm}$ dan disemprot dengan pereaksi semprot yang sesuai untuk masing-masing senyawa. Harga Rf dan warna bercak dibandingkan dengan pustaka.

\section{HASIL}

Hasil uji kelarutan ekstrak, menunjukkan bahwa ekstrak etanol biji bidara laut dapat larut dalam akuades karena tidak adanya endapan yang terjadi, sedangkan ekstrak kloroform biji bidara laut yang dilarutkan dengan propilen glikol 5\% (PG 5\%) menunjukkan hasil yang sama yaitu tidak adanya endapan yang terjadi.

Uji kelarutan ekstrak sangat penting untuk dilakukan karena berkaitan dengan metode uji antibakteri yang digunakan. Metode uji antibakteri yang digunakan adalah dilusi cair, dimana pada metode ini bakteri uji akan terdispersi merata dalam ekstrak (larutan) uji, sehingga kelarutan ekstrak (larutan) uji sangat penting. Kelarutan ekstrak uji ini berkaitan juga dengan kontak ekstrak dengan bakteri.

Uji pendahuluan terhadap aktivitas antibakteri dilakukan untuk mengetahui konsentrasi terkecil/terendah (KHM/KBM) dari ekstrak uji yang dapat menghambat serta membunuh bakteri uji sehingga hasil $\mathrm{KHM} / \mathrm{KBM}$ uji pendahuluan ini akan digunakan pada uji sesungguhnya.

Hasil konsentrasi hambat minimum (KHM) dan konsentrasi bunuh minimum (KBM) uji pendahuluan aktivitas antibakteri ekstrak kloroform dan ekstrak etanol 70\% biji bidara laut terhadap Stapylococcus aureus ATCC 25923 dan Salmonella thypi seperti terlihat pada tabel 1 dan 2 .

Tabel 1. Hasil KHM dan KBM uji pendahuluan aktivitas antibakteri ekstrak kloroform biji bidara laut terhadap Staphylococcus aureus ATCC 25923 dan Salmonella thypi

\begin{tabular}{|c|c|c|c|c|c|c|c|}
\hline \multirow[t]{2}{*}{ No. } & \multirow[t]{2}{*}{$\begin{array}{c}\text { Konsentrasi } \\
\% \mathrm{~b} / \mathrm{v}\end{array}$} & \multicolumn{2}{|c|}{$\begin{array}{l}\text { Stapylococcus } \\
\text { aureus }\end{array}$} & \multirow{2}{*}{ No } & \multirow{2}{*}{$\begin{array}{c}\text { Konsentrasi } \\
\% \mathrm{~b} / \mathrm{v}\end{array}$} & \multicolumn{2}{|c|}{ Salmonella thypi } \\
\hline & & $\mathrm{K} / \mathrm{J}$ & PK & & & $\mathrm{K} / \mathrm{J}$ & PK \\
\hline 1 & 50 & $\mathrm{~K}$ & & 1 & 50 & $\mathrm{~K}$ & \\
\hline 2 & 25 & $\mathrm{~K}$ & & 2 & 25 & $\mathrm{~K}$ & \\
\hline 3 & 12,5 & $\mathrm{~K}$ & & 3 & 12,5 & $\mathrm{~K}$ & \\
\hline 4 & 6,25 & $\mathrm{~K}$ & + & 4 & 6,25 & $\mathrm{~K}$ & \\
\hline 5 & 3,12 & $\mathrm{~K}$ & + & 5 & 3,12 & $\mathrm{~K}$ & + \\
\hline 6 & 1,56 & $\mathrm{~K}$ & + & 6 & 1,56 & $\mathrm{~K}$ & + \\
\hline 7 & KB & $\mathrm{K}$ & + & 7 & KB & $\mathrm{K}$ & + \\
\hline 8 & $\mathrm{KP}$ & $\mathrm{J}$ & & 8 & $\mathrm{KP}$ & $\mathrm{J}$ & \\
\hline 9 & $\mathrm{KE}$ & $\mathrm{J}$ & & 9 & $\mathrm{KE}$ & $\mathrm{J}$ & \\
\hline 10 & KM & $\mathrm{J}$ & & 10 & KM & $\mathrm{J}$ & \\
\hline
\end{tabular}

Keterangan:

$\begin{array}{ll}\mathrm{K} & =\text { Keruh } \\ \mathrm{J} & =\text { Jernih } \\ \mathrm{KB} & =\text { Kontrol Bakteri } \\ \mathrm{KP} & =\text { Kontrol Pelarut } \\ \mathrm{KE} & =\text { Kontrol Ekstrak }\end{array}$

$\mathrm{KM}=$ Kontrol Media

PK $\quad=$ Pertumbuhan Koloni Bakteri

$+\quad=$ Ada pertumbuhan koloni bakteri

$=$ Tidak ada pertumbuhan koloni bakteri 
Tabel 2. Hasil KHM dan KBM uji pendahuluan aktivitas antibakteri ekstrak etanol $70 \%$ biji bidara laut terhadap Staphylococcus aureus ATCC 25923 dan Salmonella thypi

\begin{tabular}{|c|c|c|c|c|c|c|c|}
\hline \multirow[t]{2}{*}{ No. } & \multirow[t]{2}{*}{$\begin{array}{l}\text { Konsentrasi } \\
\% \mathrm{~b} / \mathrm{v}\end{array}$} & \multicolumn{2}{|c|}{$\begin{array}{l}\text { Stapylococcus } \\
\text { aureus }\end{array}$} & \multirow[t]{2}{*}{ No } & \multirow[t]{2}{*}{$\begin{array}{l}\text { Konsentrasi } \\
\% \mathrm{~b} / \mathrm{v}\end{array}$} & \multicolumn{2}{|c|}{ Salmonella thypi } \\
\hline & & $\mathrm{K} / \mathrm{J}$ & PK & & & $\mathrm{K} / \mathrm{J}$ & PK \\
\hline 1 & 50 & $\mathrm{~K}$ & & 1 & 50 & $\mathrm{~K}$ & \\
\hline 2 & 25 & $\mathrm{~K}$ & & 2 & 25 & $\mathrm{~K}$ & \\
\hline 3 & 12,5 & $\mathrm{~K}$ & + & 3 & 12,5 & $\mathrm{~K}$ & + \\
\hline 4 & 6,25 & $\mathrm{~K}$ & + & 4 & 6,25 & $\mathrm{~K}$ & + \\
\hline 5 & 3,12 & $\mathrm{~K}$ & + & 5 & 3,12 & $\mathrm{~K}$ & + \\
\hline 6 & 1,56 & $\mathrm{~K}$ & + & 6 & 1,56 & $\mathrm{~K}$ & + \\
\hline 7 & $\mathrm{~KB}$ & $\mathrm{~K}$ & + & 7 & $\mathrm{~KB}$ & $\mathrm{~K}$ & + \\
\hline 8 & KP & $\mathrm{J}$ & & 8 & KP & $\mathrm{J}$ & \\
\hline 9 & $\mathrm{KE}$ & $\mathrm{J}$ & & 9 & $\mathrm{KE}$ & $\mathrm{J}$ & \\
\hline 10 & KM & $\mathrm{J}$ & & 10 & $\mathrm{KM}$ & $\mathrm{J}$ & \\
\hline
\end{tabular}

Tabel 3. Hasil KHM dan KBM ekstrak kloroform biji bidara laut terhadap Staphylococcus aureus ATCC 25923

\begin{tabular}{|c|c|c|c|c|c|c|c|}
\hline \multirow[t]{2}{*}{ No. } & \multirow{2}{*}{$\begin{array}{l}\text { Konsentrasi } \\
\% \mathrm{~b} / \mathrm{v}\end{array}$} & \multicolumn{2}{|c|}{ Replika I } & \multirow[t]{2}{*}{ No } & \multirow{2}{*}{$\begin{array}{l}\text { Konsentrasi } \\
\% \mathrm{~b} / \mathrm{v}\end{array}$} & \multicolumn{2}{|c|}{ Replika II } \\
\hline & & $\mathrm{K} / \mathrm{J}$ & PK & & & $\mathrm{K} / \mathrm{J}$ & PK \\
\hline 1 & 12,5 & K & & 1 & 12,5 & K & \\
\hline 2 & 11,25 & $\mathrm{~K}$ & & 2 & 11,25 & K & \\
\hline 3 & 10 & $\mathrm{~K}$ & & 3 & 10 & K & \\
\hline 4 & 8,75 & $\mathrm{~K}$ & & 4 & 8,75 & K & \\
\hline 5 & 7,5 & $\mathrm{~K}$ & + & 5 & 7,5 & K & + \\
\hline 6 & 6,25 & K & + & 6 & 6,25 & K & + \\
\hline 7 & $\mathrm{~KB}$ & K & + & 7 & KB & K & + \\
\hline 8 & $\mathrm{KP}$ & $\mathrm{J}$ & & 8 & $\mathrm{KP}$ & $\mathrm{J}$ & \\
\hline 9 & $\mathrm{KE}$ & K & & 9 & $\mathrm{KE}$ & K & \\
\hline 10 & KM & $\mathrm{J}$ & & 10 & KM & $\mathrm{J}$ & \\
\hline
\end{tabular}

Tabel 4. Hasil KHM dan KBM ekstrak kloroform biji bidara laut terhadap Salmonella thypi

\begin{tabular}{|c|c|c|c|c|c|c|c|}
\hline \multirow[t]{2}{*}{ No. } & \multirow{2}{*}{$\begin{array}{l}\text { Konsentrasi } \\
\% \mathrm{~b} / \mathrm{v}\end{array}$} & \multicolumn{2}{|c|}{ Replika I } & \multirow[t]{2}{*}{ No } & \multirow{2}{*}{$\begin{array}{l}\text { Konsentrasi } \\
\% \mathrm{~b} / \mathrm{v}\end{array}$} & \multicolumn{2}{|c|}{ Replika II } \\
\hline & & $\mathrm{K} / \mathrm{J}$ & PK & & & $\mathrm{K} / \mathrm{J}$ & PK \\
\hline 1 & 6,12 & $\mathrm{~K}$ & & 1 & 6,12 & K & \\
\hline 2 & 5,62 & $\mathrm{~K}$ & & 2 & 5,62 & $\mathrm{~K}$ & \\
\hline 3 & 5,12 & $\mathrm{~K}$ & & 3 & 5,12 & K & \\
\hline 4 & 4,62 & $\mathrm{~K}$ & & 4 & 4,62 & K & \\
\hline 5 & 4,12 & $\mathrm{~K}$ & & 5 & 4,12 & K & \\
\hline 6 & 3,62 & $\mathrm{~K}$ & & 6 & 3,62 & K & \\
\hline 7 & 3,12 & $\mathrm{~K}$ & + & 7 & 3,12 & K & + \\
\hline 8 & KB & $\mathrm{K}$ & + & 8 & KB & K & + \\
\hline 9 & KP & $\mathrm{J}$ & & 9 & $\mathrm{KP}$ & $\mathrm{J}$ & \\
\hline 10 & $\mathrm{KE}$ & K & & 10 & $\mathrm{KE}$ & K & \\
\hline 11 & KM & $\mathrm{J}$ & & 11 & KM & $\mathrm{J}$ & \\
\hline
\end{tabular}


Tabel 5. Hasil KHM dan KBM ekstrak etanol 70\% biji bidara laut terhadap Staphylococcus aureus ATCC 25923

\begin{tabular}{l|l|l|l|l|l|l|l}
\hline \multirow{2}{*}{ No. } & $\begin{array}{l}\text { Konsentrasi } \\
\% \text { b/v }\end{array}$ & \multicolumn{2}{l}{ Replika I } & No & $\begin{array}{l}\text { Konsentrasi } \\
\% \text { b/v }\end{array}$ & \multicolumn{2}{l}{ Replika II } \\
\cline { 5 - 8 } & K/J & PK & & & K/J & PK \\
\hline 1 & 25 & J & & 1 & 25 & J & \\
\hline 2 & 23,75 & J & & 2 & 23,75 & J & \\
\hline 3 & 22,50 & J & & 3 & 22,50 & J & \\
\hline 4 & 21,25 & J & & 4 & 21,25 & J & \\
\hline 5 & 20 & J & & 5 & 20 & J & \\
\hline 6 & 18,75 & K & & 6 & 18,75 & K & \\
\hline 7 & 17,5 & K & & 7 & 17,5 & K & \\
\hline 8 & 16,25 & K & & 8 & 16,25 & K & \\
\hline 9 & 15 & K & & 9 & 15 & K & \\
\hline 10 & 13,75 & K & + & 10 & 13,75 & K & + \\
\hline 11 & 12,5 & K & + & 11 & 12,5 & K & + \\
\hline 12 & 11,25 & K & + & 12 & 11,25 & K & + \\
\hline 13 & KB & K & + & 13 & KB & K & + \\
\hline 14 & KP & J & & 14 & KP & J & \\
\hline 15 & KE & J & & 15 & KE & J & \\
\hline 16 & KM & J & & 16 & KM & J & \\
\hline & & & & & & \\
\hline
\end{tabular}

Tabel 6. Hasil KHM dan KBM ekstrak etanol 70\% biji bidara laut terhadap Salmonella thypi

\begin{tabular}{|c|c|c|c|c|c|c|c|}
\hline \multirow[t]{2}{*}{ No. } & \multirow{2}{*}{$\begin{array}{l}\text { Konsentrasi } \\
\% \mathrm{~b} / \mathrm{v}\end{array}$} & \multicolumn{2}{|c|}{ Replika I } & \multirow[t]{2}{*}{ No } & \multirow{2}{*}{$\begin{array}{l}\text { Konsentrasi } \\
\% \mathrm{~b} / \mathrm{v}\end{array}$} & \multicolumn{2}{|c|}{ Replika II } \\
\hline & & $\mathrm{K} / \mathrm{J}$ & $\mathrm{PK}$ & & & $\mathrm{K} / \mathrm{J}$ & PK \\
\hline 1 & 24,5 & $\mathrm{~K}$ & & 1 & 24,5 & K & \\
\hline 2 & 23,5 & $\mathrm{~K}$ & & 2 & 23,5 & $\mathrm{~K}$ & \\
\hline 3 & 22,5 & $\mathrm{~K}$ & & 3 & 22,5 & K & \\
\hline 4 & 21,5 & $\mathrm{~K}$ & + & 4 & 21,5 & K & + \\
\hline 5 & 20,5 & $\mathrm{~K}$ & + & 5 & 20,5 & $\mathrm{~K}$ & + \\
\hline 6 & 19,5 & $\mathrm{~K}$ & + & 6 & 19,5 & K & + \\
\hline 7 & 18,5 & $\mathrm{~K}$ & + & 7 & 18,5 & $\mathrm{~K}$ & + \\
\hline 8 & 17,5 & $\mathrm{~K}$ & + & 8 & 17,5 & $\mathrm{~K}$ & + \\
\hline 9 & 16,5 & $\mathrm{~K}$ & + & 9 & 16,5 & $\mathrm{~K}$ & + \\
\hline 10 & 15,5 & K & + & 10 & 15,5 & K & + \\
\hline 11 & 14,5 & $\mathrm{~K}$ & + & 11 & 14,5 & $\mathrm{~K}$ & + \\
\hline 12 & 13,2 & $\mathrm{~K}$ & + & 12 & 13,2 & $\mathrm{~K}$ & + \\
\hline 13 & 12,5 & $\mathrm{~K}$ & + & 13 & 12,5 & $\mathrm{~K}$ & + \\
\hline 14 & KB & K & + & 14 & KB & K & + \\
\hline 15 & $\mathrm{KP}$ & $\mathrm{J}$ & & 15 & KP & $\mathrm{J}$ & \\
\hline 16 & $\mathrm{KE}$ & $\mathrm{J}$ & & 16 & $\mathrm{KE}$ & $\mathrm{J}$ & \\
\hline 17 & KM & $\mathrm{J}$ & & 17 & KM & $\mathrm{J}$ & \\
\hline
\end{tabular}

Tabel 7. Hasil Pemeriksaan Kromatografi Ekstrak Kloroform dan Ekstrak Etanol 70\% Biji bidara Laut Untuk Senyawa Alkaloid

\begin{tabular}{|c|c|c|c|c|c|c|}
\hline \multirow{2}{*}{ Cuplikan } & \multirow[t]{2}{*}{ No. } & \multirow[t]{2}{*}{$\mathrm{Rf}$} & \multicolumn{3}{|l|}{ Deteksi } & \multirow[t]{2}{*}{ Alkaloid } \\
\hline & & & $\mathrm{UV}_{254 \mathrm{~nm}}$ & $\mathrm{UV}_{366 \mathrm{~nm}}$ & Dragendroff & \\
\hline Ekstrak $\mathrm{CHCl}_{3}$ & 1 & 0,62 & $\begin{array}{l}\text { Berfluoresensi } \\
\text { ungu }\end{array}$ & $\begin{array}{l}\text { Berfluoresensi } \\
\text { biru }\end{array}$ & Bercak coklat & + \\
\hline
\end{tabular}




\begin{tabular}{l|l|l|l|l|l|l}
\hline Ekstrak etanol & 1 & 0,87 & $\begin{array}{l}\text { Berfluoresensi } \\
\text { ungu }\end{array}$ & $\begin{array}{l}\text { Berfluoresensi } \\
\text { biru }\end{array}$ & Bercak coklat & + \\
\hline Cofein & 1 & 0,94 & $\begin{array}{l}\text { Berfluoresensi } \\
\text { ungu }\end{array}$ & $\begin{array}{l}\text { Berfluoresensi } \\
\text { biru }\end{array}$ & $\begin{array}{l}\text { Bercak coklat } \\
\text { muda }\end{array}$ & + \\
\hline
\end{tabular}

Tabel 8. Hasil Pemeriksaan Kromatografi Ekstrak Kloroform dan Ekstrak Etanol 70\% Biji bidara Laut Untuk Senyawa Tanin

\begin{tabular}{c|c|c|c|c|c|c}
\hline \multirow{2}{*}{ Cuplikan } & No. & Rf & \multicolumn{3}{|c}{ Deteksi } & \multirow{2}{*}{ Tanin } \\
\cline { 4 - 7 } & & & $\mathrm{UV}_{254 \mathrm{~nm}}$ & $\mathrm{UV}_{366 \mathrm{~nm}}$ & $\mathrm{FeCl}_{3}$ & \\
\hline Ekstrak $\mathrm{CHCl}_{3}$ & 1 & 0,31 & - & Berfluoresensi ungu & Coklat & - \\
\hline Ekstrak etanol & 1 & 0,87 & - & Berfluoresensi ungu & Biru & + \\
\hline Tanin & 1 & 0,81 & - & Berfluoresensi ungu & Biru & + \\
\hline
\end{tabular}

Tabel 9. Hasil Pemeriksaan Kromatografi Ekstrak Kloroform dan Ekstrak Etanol 70\% Biji bidara Laut Untuk Senyawa Steroid/Triterpenoid

\begin{tabular}{|c|c|c|c|c|c|c|}
\hline \multirow[t]{2}{*}{ Cuplikan } & \multirow[t]{2}{*}{ No. } & \multirow[t]{2}{*}{$\mathrm{Rf}$} & \multicolumn{3}{|c|}{ Deteksi } & \multirow[t]{2}{*}{ Steroid } \\
\hline & & & $\mathrm{UV}_{254 \mathrm{~nm}}$ & $\mathrm{UV}_{366 \mathrm{~nm}}$ & Pereaksi LB & \\
\hline Ekstrak $\mathrm{CHCl}_{3}$ & 1 & 0,00 & - & Berfluoresensi biru & Coklat & + \\
\hline Ekstrak etanol & 1 & 0,94 & - & Berfluoresensi biru & Coklat & + \\
\hline Klerak & 1 & 0,87 & . & Berfluoresensi biru & Coklat & + \\
\hline
\end{tabular}

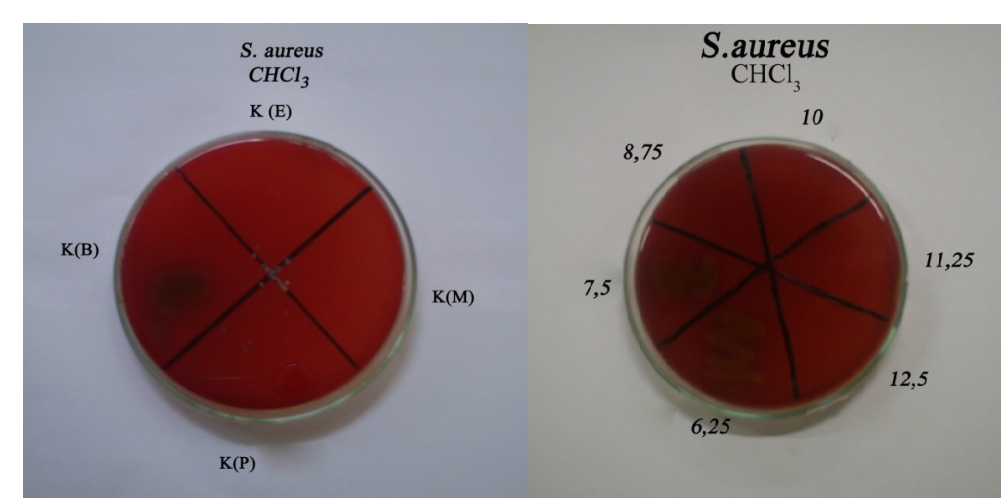

Gambar 1. Hasil KBM ekstrak kloroform biji bidara laut terhadap Stapylococcus aureus ATCC 25923 (KB: Kontrol Bakteri, KP: Kontrol Pelarut, KE: Kontrol Ekstrak, KM: Kontrol Media, 12,5\% - 6,25\%: Konsentrasi ekstrak/larutan uji)

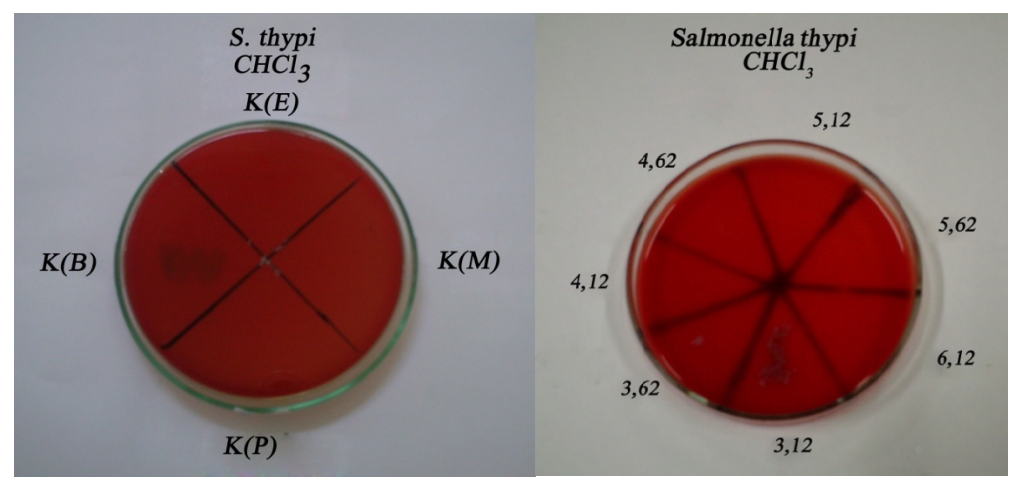

Gambar 2. Hasil KBM ekstrak kloroform biji bidara laut terhadap Salmonella thypi 


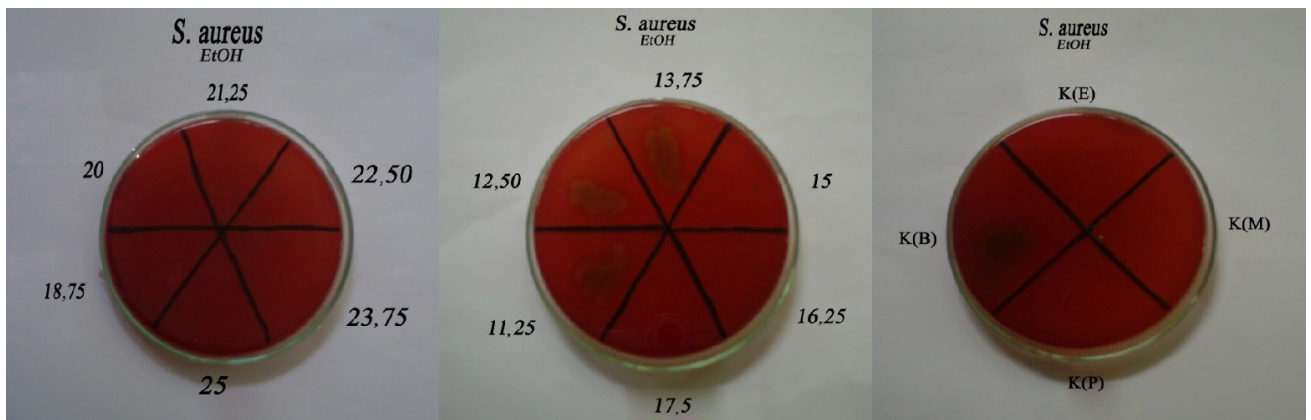

Gambar 3. Hasil KBM ekstrak etanol 70\% biji bidara laut terhadap Stapylococcus aureus ATCC 25923

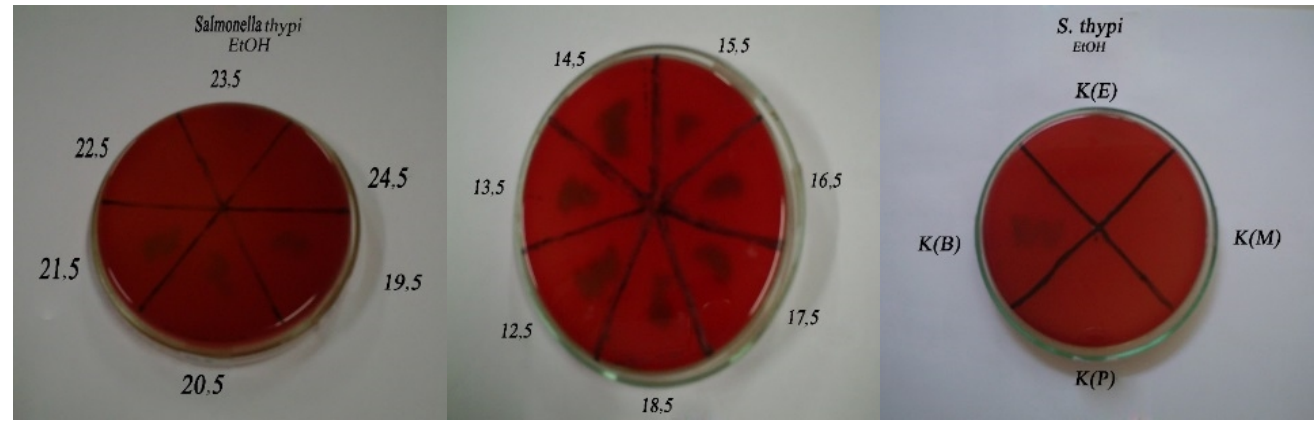

Gambar 4. Hasil KBM ekstrak etanol 70\% biji bidara laut terhadap Salmonella thypi

\section{PEMBAHASAN}

Hasil penelitian menunjukkan bahwa KHM dari kedua ekstrak uji (ekstrak kloroform dan ekstrak etanol 70\%) biji bidara laut tidak dapat ditentukan, hal ini disebabkan oleh warna larutan uji baik yang memiliki konsentrasi besar maupun konsentrasi kecil menampakkan warna yang hampir sama (keruh) sehingga sulit untuk membedakan apakah warna keruh tersebut disebabkan oleh adanya bakteri yang mati atau karena keruhnya larutan uji itu sendiri. KBM dari kedua ekstrak uji dapat diketahui setelah masing-masing konsentrasi larutan uji digoreskan pada media agar darah yang ditunjukkan oleh tidak adanya pertumbuhan bakteri pada media tersebut.

Berdasarkan hasil uji pendahuluan aktivitas antibakteri ekstrak kloroform dan ekstrak etanol $70 \%$ biji bidara laut, maka didapatkan konsentrasi bunuh minimum (KBM) dari larutan uji yang dapat menghambat/membunuh Staphylococcus aureus dan Salmonella thypi, dimana konsentrasi tersebut akan digunakan dalam uji sesungguhnya. Hasil KBM dari uji pendahuluan aktivitas antibakteri adalah $12,5 \%$ untuk $S$. aureus ekstrak kloroform, $6,12 \%$ untuk $S$. thypi ekstrak kloroform, dan $25 \%$ untuk $S$. aureus dan $S$. thypi ekstrak etanol. Hasil KHM dan KBM aktivitas antibakteri ekstrak kloroform biji bidara laut terhadap Stapylococcus aureus ATCC 25923 dan Salmonella thypi (Gambar 1 dan 2, serta Tabel 3 dan 4).

Ekstrak kloroform biji bidara laut memiliki KBM yang lebih rendah/kecil dari pada ekstrak etanol biji 70\% bidara laut, baik terhadap $S$. aureus maupun terhadap $S$. thypi. Perbedaan KBM kedua ekstrak uji disebabkan oleh sifat dari kedua ekstrak uji (kloroform dan etanol 70\%) biji bidara laut tersebut berbeda, dimana ekstrak kloroform biji bidara laut memiliki sifat non polar (senyawa lipofilik), sedangkan ekstrak etanol biji bidara laut memiliki sifat polar (senyawa hidrofilik). Senyawa-senyawa lipofilik lebih efektif dalam menyerang dinding sel dan membran sel bakteri. Kerusakan pada dinding sel dan membran sel dapat menyebabkan kematian bagi sel bakteri. Selain dipengaruhi oleh sifat dari kedua ekstrak uji, besar kecilnya KBM juga dipengaruhi oleh struktur dan susunan (komposisi) sel kedua bakteri uji yang berbeda.

Ekstrak kloroform biji bidara laut lebih poten terhadap $S$. thypi dari pada $S$. aureus. Ekstrak kloroform biji bidara laut mengandung senyawa lipofilik, sehingga senyawa-senyawa 
tersebut lebih mudah menembus dinding sel $S$. thypi yang tersusun oleh sebagian besar komponen lipofilik seperti lipopolisakarida, lipoprotein, fosfolipid (lapisan luar) dan lapisan peptidoglikan yang tipis. Dengan susunan tersebut mempermudah senyawasenyawa dalam ekstrak kloroform biji bidara laut untuk menembus dinding sel $S$. thypi. Dinding sel $S$. aureus tersusun atas lapisan peptidoglikan relatif tebal yang dikelilingi oleh asam teikoat. Dengan komposisi dinding sel tersebut menyebabkan terhambatnya ekstrak kloroform biji bidara laut untuk memasuki dinding sel $S$. aureus. Dinding sel mempunyai fungsi pelindung yang penting bagi bakteri terhadap senyawa-senyawa (lingkungan luar sel) yang mengganggu (Page dan College, 1997). Dengan rusaknya dinding sel, maka hilang pertahanan bagi $S$. thypi dan $S$. aureus sehingga dengan mudah ekstrak kloroform (senyawa yang terkandung dalam ekstrak kloroform biji bidara laut yaitu alkaloid dan steroid/triterpenoid) masuk ke dalam membran sel $S$. thypi dan $S$. aureus dan merusak komponen-komponen penyusun membran sel yang akhirnya menyebabkan kerusakan/kematian terhadap sel bakteri.

Ekstrak etanol biji bidara laut memiliki KBM yang berbeda terhadap $S$. aureus dan $S$. thypi. KBM ekstrak etanol $70 \%$ biji bidara laut menunjukkan bahwa ekstrak etanol biji bidara laut lebih poten terhadap $S$. aureus dari pada $S$. thypi. Hal ini disebabkan oleh perbedaan komposisi/susunan dinding sel dari kedua bakteri. Dinding sel $S$. aureus tersusun oleh lapisan peptidoglikan yang tebal, dimana lapisan ini terdiri dari sebagian besar komponen hidrofil. Dengan susunan tersebut mempermudah ekstrak etanol (senyawa hidrofilik) untuk menembus dinding sel $S$. aureus. Dinding sel $S$. thypi tersusun atas lapisan luar (sebagian besar komponen lipofilik) dan lapisan dalam yang tipis. Adanya lapisan luar dari dinding sel $S$. thypi menyebabkan terhalangnya ekstrak etanol biji bidara laut untuk masuk/menembus dinding sel S. thypi. Kemungkinan ekstrak etanol 70\% biji bidara laut lebih mudah melancarkan efek antibakterinya terhadap dinding sel bakteri, karena dinding sel bakteri tersusun oleh sebagian besar komponen hidrofilik. Hasil analisis dengan kromatografi menunjukkan bahwa ekstrak etanol $70 \%$ biji bidara laut mengandung senyawa alkaloid, steroid/triterpenoid dan tanin. Senyawasenyawa tersebut memiliki aktivitas sebagai antibakteri, dimana senyawa alkaloid mampu memasuki (merusak) dinding sel bakteri, steroid/triterpenoid dapat menganggu/merusak membran sel bakteri, sedangkan tanin memiliki kemampuan untuk berikatan dengan protein bakteri sehingga menyebabkan protein terdenaturasi, menghambat kerja enzim, merusak membran sel, sehingga mengakibatkan terhambatnya pertumbuhan sel atau matinya sel (Robinson, 1991; Anief, 2000; Cowan, 1999).

Berdasarkan konsentrasi bunuh minimum (KBM) dari kedua ekstrak, dapat dipastikan bahwa ekstrak kloroform biji bidara laut memiliki aktivitas antibakteri yang lebih baik (lebih poten) dari pada ekstrak etanol biji bidara laut, baik terhadap $S$. aureus. maupun terhadap S. thypi.

Analisis kandungan kimia ekstrak kloroform dan ekstrak etanol $70 \%$ biji bidara laut untuk senyawa alkaloid dan steroid/triterpenoid menggunakan kromatografi lapis tipis, sedangkan senyawa tanin menggunakan kromatografi kertas. Hasil analisis kandungan kimia ekstrak menggunakan kromatografi menunjukkan bahwa ekstrak kloroform biji bidara laut mengandung senyawa alkaloid dan steroid/triterpenoid, sedangkan ekstrak etanol $70 \%$ biji bidara laut mengandung senyawa alkaloid, steroid/triterpenoid dan tanin. Cuplikan dibuat dengan konsentrasi 2,5\% dan setiap cuplikan ditotolkan sebanyak 3 kali totolan menggunakan pipa kapiler. Hasil analisis dengan kromatografi terhadap senyawa alkaloid, tanin, dan steroid/triterpenoid dari ekstrak kloroform dan ekstrak etanol $70 \%$ biji bidara laut (tabel $7,8,9)$.

Berdasarkan hasil kromatografi lapis tipis (KLT) dan kromatografi kertas (Kkt), bahwa dalam ekstrak kloroform dan ekstrak etanol $70 \%$ biji bidara laut terkandung senyawa alkaloid, tanin dan steroid/triterpenoid. 
Senyawa-senyawa ini lebih dikenal memiliki aktivitas sebagai antibakteri. Ekstrak kloroform dan ekstrak etanol 70\% biji bidara laut memiliki potensi sebagai senyawa antibakteri sehingga perlu dilakukan penelitian lebih lanjut terhadap ekstrak kloroform dan ekstrak etanol $70 \%$ biji bidara laut.

\section{KESIMPULAN}

1. Ekstrak kloroform dan ekstrak etanol $70 \%$ biji bidara laut (Strychnos ligustrina B1) memiliki aktivitas sebagai antibakteri terhadap Stapylococcus aureus ATCC 25923 dan Salmonella thypi.

2. Kadar hambat minimum (KHM) dalam penelitian ini tidak dapat ditentukan, sedangkan nilai konsentrasi bunuh minimum (KBM) ekstrak kloroform biji bidara laut adalah 3,62\% untuk Salmonella thypi dan 8,75\% untuk Stapylococcus aureus ATCC 25923, ekstrak etanol 70\% biji bidara laut memiliki KBM 22,5\% untuk Salmonella thypi dan 15\% untuk Stapylococcus aureus ATCC 25923.

3. Ekstrak kloroform biji Strychnos ligustrina Bl. memiliki aktivitas antibakteri lebih baik (lebih poten) dari pada ekstrak etanol 70\% biji Strychnos ligustrina Bl, baik terhadap Salmonella thypi maupun Stapylococcus aureus ATCC 25923.

4. Senyawa yang terkandung dalam ekstrak kloroform biji bidara laut yaitu alkaloid dan steroid/triterpenoid, sedangkan senyawa yang terkandung dalam ekstrak etanol 70\% biji bidara laut adalah alkaloid, tanin dan steroid/triterpenoid.

\section{DAFTAR PUSTAKA}

Anief M. 2000. Penggolongan Obat Berdasarkan Khasiat dan Penggunaan. Edisi keempat. Yogyakarta: Gadjah Mada University Press.

Cowan MM. 1999. Plant Products as Antimicrobial Agents. American Sosiety for Microbiology. http//:www.asm.org. Diakses 20 Januari 2013.

Jamal Y, Praptiwi, dan Agusta A. 2001. Penapisan Fitokimia, Uji Toksisitas dan Antibakteri dari Ekstrak Kulit Batang
Garcinia celebica dan G. tetandra, Bogor: Majalah Farmasi Indonesia, Balit. Botani-Puslit.Biologi-LIPI. vol 12(4). 181-185.

Mursiti H, dan Hertiani T. 2002. Uji Toksisitas Fraksi Aktif Ekstrak Kloroform Biji Phaleria macrocarpa (Scheff.) Boerl Terhadap Artemia salina Leach, Pharmacon. Yogyakarta: Fakultas Farmasi Universitas Gadjah Mada. vol 3(2):46-50.,

Page SD, College B. 1997. Prinsip-prinsip Biokimia. Edisi Kedua. Jakarta: Penerbit Erlangga.

Rachmat J, Prana KT, dan Simanjuntak P. 2002. Isolasi dan Penentuan Struktur Molekul Alkaloid dari Strychnos ligustrina B1 (Loganiaceae). Jakarta: Pusat Penelitian Bioteknologi LIPI dan Fakultas farmasi, Universitas Pancasila. vol 1 (1):1.

Robinson T. 1991. Kandungan Organik Tumbuhan Tinggi. Diterjemahkan oleh Kosasih P. Bandung: Institut Teknologi Bandung Press.

Slamet SJ. 2004. Kesehatan Lingkungan. Yogyakarta: Gadjah Mada University Press.

Stephen CE, Stephen AB. 1986. Antibiotik dan Infeksi. Jakarta: Penerbit Buku Kedokteran EGC.

Tjitrosoepomo G. 1994. Taksonomi Tumbuhan Obat-Obatan. Yogyakarta: Gadjah Mada University Press.

Tjitrosoepomo G. 2003. Taksonomi Tumbuhan (Schyzophyta, Thallophyta, Bryophyta, Pteridophyta). Yogyakarta: Gadjah Mada University Press.

Voigh R. 1995. Lehrbuch Der Pharmazeutischen Tecnologie, Diterjemahkan oleh Volk dan Gesundheit, Buku Pelajaran Teknologi Farmasi. Yogyakarta: Gadjah Mada University Press.

Waluyo L. 2005. Mikrobiologi Umum. Edisi pertama. Malang: Universitas Muhammadiyah Malang Press.

Volk dan Wheeler. 1990. Mikrobiologi Dasar. Edisi kelima. Jakarta: Penerbit Erlangga. 